\title{
UTILIZATION OF RICE STRAW FOR FEEDING RUMINANTS: 3- COMPARATIVE STUDIES BETWEEN CORN STALKS AND GREEN RICE STRAW SILAGE DURING SUMMER FEEDING
}

El-Giziry, A. A. ; M. A. A. Abd El-Hady ; M. M. Bendary; M. F. Sadek and Kh. M. M. Mousa

Animal Prod. Research Institute, Agric. Res. Centre, Dokki, Giza, Egypt. E-mail: amraligz@yahoo.com

\begin{abstract}
Two comparative studies between green corn stalks silage (CSS) and green rice straw silage (RSS) were conducted. The $1^{\text {st }}$ one was to evaluate the nutritional values of both kinds of silages using 6 adult rams in two digestion trials ( 3 in each). The other comparative study was carried out in summer season using swing-over method to investigate productive performance of lactating buffaloes which fed rations containing either green corn stalks or rice straw silages.

Eight lactating buffaloes average $500-600 \mathrm{~kg}$ body weight at $2 \mathrm{nd}$ to 5 th parities were used after 8 weeks of calving. Animals were fed three tested rations, the control (CR) represented traditional summer rations which composed of $53 \%$ concentrate feed mixture (CFM), $20 \%$ berseem hay (BH) $27 \%$ rice straw (RS) and the 1st tested ration (TR1) contained $42 \%$ CFM, $43 \%$ RSS and $15 \% \mathrm{BH}$, while the 2nd tested ration (TR2) was CFM, CSS and BH to supply 42,43 and $15 \%$ of the daily DM intake, respectively. The impact of ensiled corn stalks and rice straw and their utilization for animal feeding per feddan was also investigated.

The two tested silages had a good fermentation quality as low values of $\mathrm{pH}$, $\mathrm{NH}_{3}-\mathrm{N}$ (\%of total $\mathrm{N}$ ) and normal concentration of VFA's. Corn stalks silage (CSS) had a higher nutritive values as TDN\%, DE and DCP\%, compared to green rice straw silage (RSS). Single crossbred of maize crop (Sc10) produced the highest silage yield / fedden being 5.13, 0.35, 0.23 and 3.03 ton/ feddan DM, CP, DCP and TDN, respectively. Corresponding values with rice straw (Sakha 104 variety) silage were 2.4, $0.14,0.10$ and $1.15 \mathrm{tan} /$ feddan.

No significant differences among tested rations for OM, EE and NFE digestibility, while the differences were significant $(P<0.05)$ in $C P$ and CF digestibility coefficients. TR2 had the highest values $(P<0.05)$ in TDN and DE followed by TR1, while control ration showed the lowest values. On the contrary, CR showed significantly $(P<0.05)$ the highest DCP value followed by TR1, while TR2 recorded the lowest value. No significant differences were observed for actual daily milk yield, while $7 \%$ FCM yield differed significantly $(\mathrm{P}<0.05)$ among the tested groups. In addition, there were significant differences in fat, lactose and total solids contents in milk, while no significant differences between groups on protein and SNF contents in milk. Buffaloes fed TR1 and TR2 recorded the best feed conversion compared with those fed CR. Daily feed cost decreased with including RSS and CSS in the $1^{\text {st }}$ and $2^{\text {nd }}$ tested rations by 14.44 and $6.95 \%$, respectively. Also gross margin over feed cost for buffaloes fed TR1 and TR2 increased by 78.9 and $100.0 \%$ compared with those fed CR. Economic efficiency improved by 34.10 and $35.23 \%$ for groups fed rations containing RSS and CSS (TR1 and TR2, respectively) compared with feeding contro ration. It could be concluded that inclusion of rice straw silage or corn stalks silage as a basal ration for lactating buffaloes in traditional summer rations led to reduce the amounts of CFM by about $20 \%$, increased daily $7 \%$ FCM by 15.03 and $26.12 \%$ and
\end{abstract}


improve economic efficiency, along with limiting the environmental pollution as a result of accumulation of rice straw or corn stalks in the fields or burning them.

Keywords: lactating buffaloes, green rice straw silage, green corn stalks silage, nutrients digestibility, milk production, economic efficiency

\section{INTRODUCTION}

One of the most critical factors that challenge animal production development is conserving sufficient amount of feedstuffs, especially green and dry forages. The traditional green forage produced in Egypt are still insufficient to satisfy livestock requirements. Animals are mainly fed on green berseem only during the winter season, while summer feeding depends mainly on agricultural by-products which are nutritionally imbalanced and don't cover the requirements of the animals either for protein or energy, especially when used without treatments to improve its nutritive value. (ElTalty et al., 2009).

However, improved feeding systems based on adding locally available feed resources will enhance milk and meat production at considerably low cost, and partially fill the gap in protein and energy shortage (El-Talty et al., 2009). Most of the available agricultural by-products are not use for animal feeding due to the lack of farmers knowledge for their importance and how to use them in feeding (Abou-Slim and Bendary 2005). Although, all studies concerning utilization of such by-products in animal feeding indicated that, incorporation of agricultural by-products as such or treated with ammonia, urea or making silage, could share in obtaining balanced summer-feeding to reduce the gab between winter and summer feeding and could decrease feeding cost along with minimizing the pollution caused by accumulation of such by-products or burn it in the field.

Some of these crops which give very huge amount of by-products are maize and rice crops. Few quantities of these residues were used for feeding animals and the major part is burned or left it in the field resulting in pollution problems. Utilization of the hall quantity of fresh corn stalks produced after harvesting maize crop (15.0 million ton/year) as silage will produce about 2.61 and 0.153 million TDN and DCP, respectively. Also, using the hall quantity of rice straw produced (3.5 million ton/year) at the national level as its or as silage along or after treated by ammonia or urea will increase about 1.26 million ton TDN to Egyptian feedstuff resources (Abou-Slim and Bendary 2005).

Therefore, the objective of the present comparative studies were to evaluate the green corn stalks silage and rice straw silage and to study the performance of lactating buffaloes fed the previous kinds of silage containing rations compared with feeding traditional summer rations.

\section{MATERIALS AND METHODS}

The present study was carried out during 2009-2010 at Animal Production Research Station, Mehallet Mousa belonging to Animal 
Production Research Institute, Ministry of Agricultural. The feeding trials lasted for 112 days.

Two comparative studies between green corn stalks (CSS) and rice straw silages (RSS) were conducted; the $1^{\text {st }}$ one was done to determine nutritional values of both kinds of silage. Rice straw silage was made immediately after harvesting grains in plastic bales $(650-750 \mathrm{~kg}$ capacity). Fresh rice straw of Sakha 104 variety (about $40 \%$ dry matter) were collected, shopped and compacted using round Baler. During compacted, rice straw were sprinkled with $50 \mathrm{~kg}$ El-Muffed liquid supplement (91\% molasses, 2.5\% urea, 1.5 mineral mixtures dissolved in $5.0 \%$ water) per ton green roughages as a main source of soluble carbohydrate to increase the moisture content of roughage and enhance the fermentation process using special sprayer contacted with the Baler. Compacted straw (bales) were covered with stretch plastic sheet using another part fixed with the baler.

Green corn stalks of Sc10 (single crossbred) of maize crop were chopped into about $1.5-2.5 \mathrm{~cm}$ length using a chopping machine immediately after harvesting grains. Fresh chopped plants (about $40 \%$ dry matter) were weighted to estimate the yield of fresh corn stalks per feddan and ensiled layer by layer (about $50 \mathrm{~cm}$ height) in the bunker. During the filling process, El-Mufeed liquid was sprinkled on the top of each layer $(50 \mathrm{~kg} / \mathrm{ton})$. Wheel tractor was used to ensure good pressing and packing of silage. When the silo was filled, it was tightly covered by plastic sheet then covered by approximately $20 \mathrm{~cm}$ layer of soil to get anaerobic conditions and ensiled for 8 weeks until starting the digestion trials. Representative samples were taken to determine silage quality. Silage $\mathrm{pH}$ was determined directly (using Orian 680 digital $\mathrm{pH}$ meter), while TVFA's and $\mathrm{NH}_{3}-\mathrm{N}$ concentration were determined according to Analytical Chemistry of Foods (1995), Warner (1964) and Bergen et al. (1974).

\section{The first trial:}

Two digestibility trials were carried out to determine nutrients digestibility coefficients and nutritive values of the two kinds of silage using 6 adult of rams (3 in each) with average body weight of $50 \mathrm{~kg}$. Rams were kept and individually fed in metabolic cages for 21 days (consisted of 14 days for adaptation and 7 days for collection). Ninety percent of ad libtium intake of the tested silage were offered for each ram in equal two meals at 8 a.m. and 4 p.m. Water was available at all times in plastic buckets. Samples of tested silages and feces were analyzed according to AOAC (1990). The obtained feeding values were applied to formulate the experimental rations of the feeding trials and to assess the quantities to cover the requirements of the experimental buffaloes.

\section{The second trial:}

The $2^{\text {nd }}$ comparative study (feeding trial) was conducted to investigate the performance of lactating buffaloes fed the tested rations containing corn stalks silage or green rice straw silage compared to the traditional summer ration. Eight lactating buffalo cows, 500-600 kg live body weight (LBW) at the $2^{\text {nd }}$ to the $5^{\text {th }}$ of lactation were used in swing-over design for 112 days (El-Serafi, 1968 and Darwish et al., 1989). Four successive experimental periods, each periods consisted of 21 days for adaptation and 7 
days for collection. The feeding experiment was started and ended with the control ration (CR) to adjust the normal daily decrease in milk yield, between them the $1^{\text {st }}$ and $2^{\text {nd }}$ tested rations (TR1 and TR2) were fed. Animals were fed the following rations on DM basis; control ration (CR) containing $53.0 \%$ concentrate feed mixture $(\mathrm{CFM})+20.0 \%$ berseem hay $(\mathrm{BH})+27.0 \%$ rice straw (RS). Tested ration one (TR1) contained $42.0 \%$ CFM $+15.0 \% \mathrm{BH}+$ $43.0 \%$ rice straw silage (RSS) and tested ration two (TR2) that contained $42.0 \% \mathrm{CFM}+15.0 \% \mathrm{BH}+43.0 \%$ corn stalks silage (CSS) as shown in Table (1).

The animals were individually fed according to Animal Production Research Institute APRI (1997) requirements of lactating buffaloes. Feeding allowances were adjusted weekly according to change in LBW and milk production. Three digestibility trials were carried out at the end of each collection period using three experimental buffaloes to evaluate nutritive values of the experimental rations. Acid insoluble ash (AIA) was used as a natural marker (Van Keulen and Young, 1977).

Individual morning and evening milk yields were recorded daily and $7 \%$ fat corrected milk (FCM) for each buffalo was calculated from daily milk yield and the percentage of milk fat using the formula of (Raafat and Saleh, 1962). Composite milk samples from consecutive morning and evening milkings were taken weekly during the experimental period in proportion to yield and analyzed for fat, protein, lactose, solids not fat (SNF), and total solids (TS) by Milko-Scan, model 133B.

Feed conversion expressed as the amounts of DM, TDN, DE and DCP required for producing $1 \mathrm{~kg} 7 \% \mathrm{FCM}$ was calculated. Economical efficiency of all tested rations was calculated as the ratio between the price of $7 \%$ FCM produced and the cost of feeds consumed based on the assumption that the price of one ton of $7 \%$ FCM was 3500 LE; CFM was 1500 LE; CSS was 150 LE, RSS was 80 LE; BH was 800 LE and RS was 100 LE during year 2009.

Data were statistically analyzed using general linear models procedure (GLM) of SAS (1996) for users guide. Duncan test within SAS program was done to determine the degree of significance among means (Duncan, 1955).

Table (1): Formulation of experimental rations (on DM basis \%).

\begin{tabular}{|l|c|c|c|}
\hline \multirow{2}{*}{\multicolumn{1}{c|}{ Ingredients }} & \multirow{2}{*}{ Control ration (CR) } & \multicolumn{2}{c|}{ Tested rations } \\
\cline { 3 - 4 } & & TR1 & TR2 \\
\hline Concentrate feed mixture (CFM) & 53.0 & 42.0 & 42.0 \\
\hline Berseem hay (BH) & 20.0 & 15.0 & 15.0 \\
\hline Rice straw (RS) & 27.0 & - & - \\
\hline Corn stalks silage (CSS) & - & - & 43.0 \\
\hline Rice straw silage (RSS) & - & 43.0 & \\
\hline
\end{tabular}

\section{RESULTS AND DISCUSSION}

First Trial:

Silage quality and nutritive value:

Results of silage quality (Table 2) indicated that values of $\mathrm{pH}$ recorded 3.9 and 4.3, VFA's (\% of DM) 1.90 and 1.60 and $\mathrm{NH}_{3}-\mathrm{N}(\%$ of total 
N) was 3.70 and $4.60 \%$ for corn stalks silage and green rice straw silage, respectively. Furthermore, the two kinds of silage were free from moldy and characterized with good color, smell and odor. Both chemical and physical properties and indicates good silage quality. Silage characteristics depend on the composition of the crop at harvesting time and profound changes that occur in the carbohydrate and nitrogen fractions during the whole conservation process (Thomas and Thomas, 1985).

Chemical composition of the two tested of silages are shown in Table (2). The DM and CF contents were nearly similar of the two tested silages, while OM, CP, EE and NFE contents were higher for corn stalks silage, showing lower content of ash compared with green rice straw silage. Nearly similar values were obtained by Ghanem et al. (2005) and Bendary et al. (2006) for rice straw silage and Bendary and Younis (1997), Ghanem et al. (2000) and Bendary et al. (2001) for corn stalks silage.

Table (2): Quality characteristics, chemical composition, digestibility and nutritive values of different tested silages.

\begin{tabular}{|l|c|c|c|}
\hline \multicolumn{1}{|c|}{ Item } & Rice straw silage & Corn stalks silage & \pm SE \\
\hline Quality characteristics: & & & \\
\hline pH value & 4.30 & 3.90 & \\
\hline TVF's \% of DM & 1.60 & 1.90 & \\
\hline NH $_{3}$-N \% of total-N & 4.60 & 3.70 & \\
\hline Chemical composition: & & & \\
\hline DM\% & 36.49 & 35.40 & \\
\hline OM & 79.91 & 90.64 & \\
\hline CP & 5.70 & 6.80 & \\
\hline CF & 30.01 & 30.26 & \\
\hline EE & 1.04 & 2.40 & \\
\hline NFE & 43.16 & 51.18 & \\
\hline Ash & 20.09 & 9.36 & \\
\hline Digestibility coefficients\% & & & \\
\hline OM & 59.75 & 62.54 & 1.68 \\
\hline CP & 70.06 & 66.58 & 1.864 \\
\hline CF & 62.73 & 62.88 & 2.103 \\
\hline EE & 77.43 & 80.50 & 2.15 \\
\hline NFE & 54.38 & 60.97 & 2.01 \\
\hline Nutritive values: & & & \\
\hline TDN \% & 48.1 & $58.97^{*}$ & 0.793 \\
\hline DE Mcal/kg DM & 2.12 & $2.60^{*}$ & 0.019 \\
\hline DCP \% & 3.99 & 4.54 & 0.164 \\
\hline
\end{tabular}

${ }^{1} \mathrm{DE}(\mathrm{Mcal} / \mathrm{kgDM})=0.04409 \times$ TDN \% NRC (1988).

* Significant at $\mathrm{P}<0.05$

Data presented in Table (2) revealed that corn stalks silage had higher digestibility of all nutrients except CF compared with rice straw silage but without significant differences between groups. Values of nutrients digestibility of tested silages were somewhat similar to those obtained by Bendary and Younis (1997), Ghanem et al. (2000) and Bendary et al. (2001) 
for corn stalks silage and Ghanem et al. (2005) and Bendary et al. (2006) for different varieties of rice straw silage made by different methods.

The lower value of nutrients digestibility with green rice straw silage might be due to lower contents of nutrient compared to those of corn stalks silage, beside physical and chemical nature of nutrient contents in the different kinds of by-products. Mean time, rice straw contained higher ash content $(20.09 \%)$ compared to $9.36 \%$ in the corn stalks silage. Also, the main reasons which might be responsible for superiority of corn stalks silage could be due to some beneficial effects like being more succulent and containing suitable amount of carotene. These factors may have resulted in some changes in digestion function, which increased the availability and utilization of nutrients in the rumen and could have a significant impact on the digestibility coefficients of corn stalks silage.

It could be noticed that the TDN, DE and DCP for CSS were significantly $(P<0.05)$ higher than those of RSS, as shown in Table (2). Higher nutritive values of CSS compared to RSS may be due to the reflection of higher nutrient contents and some essential factors such as minerals and vitamins in fresh corn stalks. Meantime rice straw in particular is high in silica with poor digestibility.

Output and utilization of ensiled green corn stalks and rice straw:

Observation concerning silage yield (ton/feddan) as fed and on DM basis, CP, DCP and TDN (Table 3) indicated that ensiled green corn stalks of Sc10 produced higher silage yield as fed and on DM basis compared with green rice straw of Sakha 104 variety (14.5 and 5.13 vs 6.5 and 2.4 ton/fed, respectively). These results were in agreements with those reported by Bendary and Younis (1997), Ghanem et al, (2000) and Bendary et al., (2001) concerning green and dried corn stalks yield while rice straw yield achieved in the present study was in accordance with the values recorded in the Agricultural Economics (1999 and 2003).

Table (3): Yields of green corn stalks and rice straw silages as fresh matter, DM, CP, DCP and TDN (ton/feddan).

\begin{tabular}{|c|c|c|c|c|c|}
\hline \multirow{2}{*}{ Item } & \multicolumn{5}{|c|}{ Silage yield (ton/feddan) } \\
\hline & Fresh & $\mathrm{DM}^{\star}$ & $\mathbf{C P}^{\star}$ & $\mathrm{DCP}^{*}$ & TDN $^{*}$ \\
\hline Green corn stalks Sc10** & 14.5 & 5.13 & 0.35 & 0.23 & 3.03 \\
\hline Green rice straw of Sakha 104 variety & 6.5 & 2.4 & 0.14 & 0.10 & 1.15 \\
\hline
\end{tabular}

It is clear from previous data (Table 3 ) that the impact of ensiled both green corn stalks and rice straw produced 5.13 and 2.4 for DM, 0.35 and 0.14 for CP, 0.23 and 0.10 for DCP and 3.03 and 1.15 for TDN ton/fed, respectively. Ensminger et al., (1990) indicated that the fresh corn stalks remaining after harvesting maize grains accounts for about one-third of the total nutritive value of the crop. Bendary and Younis (1997) indicated that, the green stalks yield of 13 hybrids and variety of maize crop ranged between 11.16 and 19.80 ton / feddan with an average of 14.30 ton as green stalks or 3.40 and 5.42 ton / feddan as DM with an average of 4.40 ton / feddan. The 
single crossbreed- 10 produced 18 and 5.42 ton / feddan green stalks as fresh or DM, respectively. Meanwhile El-Ready, (2000) and Bendary et al. (2006) showed that ensiled green maize stalks or rice straw produced more palatable feedstuffs than using it in dried form or leaving it in the fields causes pollution problems.

The findings of the present comparative studies and the previous works concerning the utilization of fresh corn stalks and rice straw silages for feeding ruminants (Bendary and Younis 1997; El-Ready, 2000; Ghanem et al., 2000; Bendary et al., 2001; El-Ashmawy, 2003). Ghanem et al. (2005); Abou-Slim and Bendary (2005) and Bendary et al. (2006) indicated that ensiled such by-products can offer a large potential source of CP, DCP and TDN for ruminants at the national level. However, offering facilities to make silage from such by-products to the farmers (training, extension, choppers ...etc) is very necessary to apply such technology to get use of crops byproducts for feeding animals and increase feed resources. At the same time, the use of such techniques can save considerable amounts of expensive concentrates and subsequently the cost of feeding will be reduced, in addition to minimize the environmental pollutions as the result of accumulation of such by-products or burning them in the fields.

\section{Second (Feeding) Trial:}

Chemical composition of ingredients and calculated composition of experimental rations are presented in Table (4). Results indicated that, composition of all calculated experimental rations were practically nearly similar in nutrients contents, with some few exceptions. Control ration (CR) contained the highest DM (89.69\%) compared to TR1 (55.19\%) and TR2 (54.48\%). The lower DM content in tested rations (TR1 and TR2) was mainly due to its contained higher proportion from silage along with the lower proportion of CFM. It could be noticed that the TR2 containing corn stalks silage appeared to higher OM, EE and NFE contents and lower DM and ash contents than the others. At the same time, TR1 containing rice straw silage tended to lower in all nutrients except CF and ash contents compared to the control ration. These differences in nutrient contents of experimental ration might be due to different proportion of $\mathrm{BH}$ and $\mathrm{CFM}$ and also different nutrient content in both kinds of silage. Such results are mainly a reflection of the chemical composition of CFM and the different kinds of silage.

Table (4): Chemical composition of ingredients and calculated composition of the experimental rations.

\begin{tabular}{|l|c|c|c|c|c|c|c|}
\hline \multirow{2}{*}{ Ingredient } & \multirow{2}{*}{ DM\% } & \multicolumn{7}{c|}{ Composition of DM basis \% } \\
\cline { 3 - 8 } & & OM & CP & CF & EE & NFE & Ash \\
\hline Conc. feed mixture (CFM) & 90.26 & 89.85 & 15.50 & 14.07 & 2.68 & 57.70 & 10.15 \\
\hline Berseem hay (BH) & 87.11 & 88.95 & 12.50 & 26.30 & 2.19 & 47.96 & 11.05 \\
\hline Corn stalks silage (CSS) & 35.40 & 90.64 & 6.80 & 30.26 & 2.40 & 51.18 & 9.36 \\
\hline Rice straw silage (RSS) & 36.49 & 79.96 & 5.70 & 30.01 & 1.04 & 43.21 & 20.09 \\
\hline Rice straw (RS) & 90.57 & 81.14 & 4.43 & 32.90 & 1.30 & 42.51 & 18.86 \\
\hline Experimental rations & 89.69 & 87.38 & 11.90 & 21.14 & 2.21 & 52.13 & 12.62 \\
\hline Control ration (CR) & 85.19 & 85.51 & 10.93 & 22.74 & 1.93 & 49.97 & 14.49 \\
\hline Tested ration 1 (TR1) & 54.48 & 90.05 & 11.43 & 22.44 & 2.49 & 53.40 & 9.95 \\
\hline Tested ration 2 (TR2) & 54.49 \\
\hline
\end{tabular}


As shown in Table (5) results of nutrient digestibility revealed that, non significant differences among the three tested rations in OM, EE and NFE digestibility, while the highest significant $(P<0.05)$ value of $C P$ was found for TR1 $(72.37 \%)$ followed by CR $(72.18 \%)$, while TR2 recorded the lowest value $(65.44 \%)$. Meantime, the present data indicated also that the $\mathrm{CF}$ digestibility in $C R$ showed significantly $(P<0.05)$ lower values $(63.77$ and 42.12\%, respectively) than TR1 and TR2.

The higher OM and CF digestibility of TR1 and TR2 than CR may be attributed to the effect of both kinds of silages, which provide stimulator factors to rumen cellulotytic and other bacteria. These factors resulted in some changes in digestive function then led to increasing the availability and utilization of nutrients in the rumen and could have a significant impact on digestion and nutritive values of tested rations. Similar results were obtained by Bendary and Younis (1997) who found that using green maize stalks silage increased digestibility coefficients of all nutrients except EE digestibility compared with feeding dried rice straw or maize stalks containing rations. Also, with Bendary et al. (2006), who found that digestibility coefficients of all nutrients were significantly higher with buffaloes fed rations containing green rice straw silage than those fed rations containing dried rice straw.

Table (5): Nutrients digestibility and nutritive values of the experimental rations using buffaloes.

\begin{tabular}{|l|c|c|c|c|}
\hline \multirow{2}{*}{ Items } & Control ration & \multicolumn{2}{c|}{ Tested rations } & \multirow{2}{*}{ \pm SE } \\
\cline { 3 - 4 }$(\mathbf{C R})$ & \multicolumn{2}{|c|}{ TR1 } & TR2 & \\
\hline Nutrients digestibility coefficients \% : & 66.36 & 0.97 \\
\hline OM & 63.77 & 66.53 & $65.44^{\mathrm{b}}$ & 1.32 \\
\hline CP & $72.18^{\mathrm{a}}$ & $72.37^{\mathrm{a}}$ & $50.46^{\mathrm{a}}$ & 2.24 \\
\hline CF & $42.12^{\mathrm{b}}$ & $57.82^{\mathrm{a}}$ & 79.06 & 2.42 \\
\hline EE & 70.76 & 71.96 & 71.69 & 1.44 \\
\hline NFE & 68.72 & 68.56 & & 0.876 \\
\hline Nutritive values: & $56.89^{\mathrm{b}}$ & $58.45^{\mathrm{b}}$ & $61.51^{\mathrm{a}}$ & 0.038 \\
\hline TDN \% & $2.51^{\mathrm{b}}$ & $2.58^{\mathrm{b}}$ & $2.71^{\mathrm{a}}$ & 0.21 \\
\hline DE Mcal/kg DM & $8.59^{\mathrm{a}}$ & $7.91^{\mathrm{b}}$ & $7.48^{\mathrm{b}}$ & 0 \\
\hline DCP \% & & &
\end{tabular}

$a$ and $b$ : values in the same row with different superscripts differ significantly $(P<0.05)$.

The current results showed that TR2 had significantly $(P<0.05)$ the highest TDN and DE. Meantime, the control ration (CR) had the lowest values, while TR1 had intermediate values. On the contrary the control ration $(\mathrm{CR})$ showed significantly $(\mathrm{P}<0.05)$ the highest $\mathrm{DCP}$ value $(8.59 \%)$ followed by TR1 $(7.91 \%)$, while TR2 recorded the lowest value $(7.48 \%)$. These might be due to lower CP content of corn stalks silage and rice straw silage along with the low proportion of concentrate feed mixture (CFM) used for formulation of TR1 and TR2 (Table 1 and 3). Generally, the present nutritive values are mainly associated with the chemical composition and proportion of the experimental feedstuffs.

Average daily feed intake $(\mathrm{kg} / \mathrm{head})$ from tested feedstuffs as fed or as DM basis are shown in Table (6). There were no significant differences 
among the different groups in dry matter intake, while the TDN, DE and DCP intakes were significantly $(P<0.05)$ different among treatments. The TDN and DE intakes were significantly $(P<0.05)$ higher with buffaloes fed corn stalks silage $(10.40 \mathrm{~kg} / \mathrm{d}$ and $45.83 \mathrm{Mcal} / \mathrm{d})$ followed by those fed rice straw silage, while these fed control ration showed the lowest TDN and DE intakes (9.69 $\mathrm{kg} / \mathrm{d}$ and $42.77 \mathrm{Mcal} / \mathrm{d}$ ). On the contrary, buffaloes fed control ration recorded the highest DCP intake (1.46 kg/day) followed by those fed TR1 (1.35 $\mathrm{kg} /$ day $)$, while buffaloes fed TR2 showed the lowest value $(1.27 \mathrm{~kg} /$ day $)$.

Table (6): Average daily feed intake of different tested rations consumed by lactating buffaloes.

\begin{tabular}{|c|c|c|c|c|}
\hline \multirow{2}{*}{ Item } & \multirow{2}{*}{$\begin{array}{c}\text { Control ration } \\
\text { (CR) }\end{array}$} & \multicolumn{2}{|c|}{ Tested rations } & \multirow{2}{*}{$\pm \mathrm{SE}$} \\
\hline & & TR1 & TR2 & \\
\hline \multicolumn{5}{|c|}{ Average daily feed intake $(\mathrm{kg} / \mathrm{head})$ as fed: } \\
\hline $\begin{array}{l}\text { Concentrate feed mixture } \\
\text { (CFM) }\end{array}$ & 10.0 & 8.0 & 8.0 & \\
\hline Berseem hay (BH) & 4.0 & 3.0 & 3.0 & \\
\hline Rice straw (RS) & 5.0 & - & - & \\
\hline Corn stalks silage (CSS) & - & - & 20.0 & \\
\hline Rice straw silage (RSS) & - & 20.0 & - & \\
\hline Total & 19.0 & 31.0 & 31.00 & \\
\hline \multicolumn{5}{|c|}{ Average daily feed intake (kg/head) on DM basis: } \\
\hline $\begin{array}{l}\text { Concentrate feed mixture } \\
\text { (CFM) }\end{array}$ & 9.03 & 7.22 & 7.22 & \\
\hline Berseem hay $(\mathrm{BH})$ & 3.48 & 2.61 & 2.61 & \\
\hline Rice straw (RS) & 4.53 & - & & \\
\hline Corn stalks silage (CSS) & - & & 7.08 & \\
\hline Rice straw silage (RSS) & - & 7.3 & - & \\
\hline Total DM intake, $\mathrm{kg} / \mathrm{h} / \mathrm{d}$ & 17.04 & 17.13 & 16.91 & \\
\hline TDN intake, $\mathrm{kg} / \mathrm{h} / \mathrm{d}$ & $9.69^{D}$ & $10.01^{\mathrm{D}}$ & $10.40^{\mathrm{a}}$ & 0.064 \\
\hline DE intake, Mcal/h/day & $42.77^{0}$ & $44.20^{\mathrm{b}}$ & $45.83^{\mathrm{a}}$ & 0.300 \\
\hline DCP intake, $\mathrm{kg} / \mathrm{h} / \mathrm{d}$ & $1.46^{\mathrm{a}}$ & $1.35^{\mathrm{b}}$ & $1.27^{\mathrm{C}}$ & 0.017 \\
\hline
\end{tabular}

Average daily milk yield and its composition of lactating buffaloes fed the experimental rations are shown in Table (7). There were insignificant differences in average daily milk yield among different group animals fed $\mathrm{CR}$, TR1, and TR2, being 10.5, 11.23 and $11.33 \mathrm{~kg} /$ day, respectively. This was not surprising since the buffaloes in all treatments received their recommended nutrients allowances (APRI, 1997). However, feeding TR1 and TR2 containing either kinds of silages led to significant $(P<0.05)$ increase in average $7 \%$ FCM being 10.79 and $11.83 \mathrm{~kg} \mathrm{7 \% FCM}$, respectively compared with $9.38 \mathrm{~kg} 7 \% \mathrm{FCM}$ for those fed traditional summer ration (CR). Corresponding significant $(\mathrm{P}<0.05)$ increase in fat content with TR1 and TR2 were observed showing 6.71 and $7.46 \%$, respectively. Also, the results showed significant $(P<0.05)$ differences among group animals in lactose and total solids contents of milk. On the contrary, significant differences among different groups in protein and SNF contents were not found (Table 7). 
Table (7): Milk production and its composition as affected by feeding tested rations.

\begin{tabular}{|l|c|c|c|c|}
\hline \multirow{2}{*}{ Item } & Control & \multicolumn{2}{c|}{ Tested rations } & \multirow{2}{*}{ \pm SSE } \\
\cline { 3 - 4 } & ration (CR) & TR1 & TR2 & \\
\hline Daily milk yield, kg & 10.50 & 11.23 & 11.33 & 0.369 \\
\hline Daily 7\%FCM yield, kg & $9.38^{\mathrm{b}}$ & $10.79^{\mathrm{a}}$ & $11.83^{\mathrm{a}}$ & 0.46 \\
\hline Milk fat, \% & $6.11^{\mathrm{b}}$ & $6.71^{\mathrm{b}}$ & $7.46^{\mathrm{a}}$ & 0.23 \\
\hline Milk protein, \% & 4.31 & 4.25 & 4.33 & 0.05 \\
\hline Milk lactose, \% & $5.36^{\mathrm{ab}}$ & $5.55^{\mathrm{a}}$ & $5.27^{\mathrm{b}}$ & 0.066 \\
\hline Milk SNF, \% & 10.27 & 10.40 & 10.20 & 0.087 \\
\hline Milk TS, \% & $16.38^{\mathrm{b}}$ & $17.11^{\mathrm{a}}$ & $17.66^{\mathrm{a}}$ & 0.231 \\
\hline
\end{tabular}

$a$ and $b$ : values in the same row with different superscripts differ significantly $(P<0.05)$

Increasing in fat percentage of milk for lactating buffaloes fed CSS and RSS probably due the effect of tested feed stuffs on rumen fermentation along with that tested silages contained suitable amounts of TVFA's. In addition, crude fiber, crude protein content and physical form of diet can influence milk composition (Davis and Brown, 1970). The increase in TS was mainly a result of an increase in the fat content of the milk of both tested groups, whereas the protein and SNF contents were not affected.

Feed conversion expressed as production efficiency is presented in Table (8). Buffaloes fed TR1 and TR2 containing rice straw silage and corn stalks silage attained the best production efficiency as DM, TDN, DE and DCP utilization efficiency compared with those fed control ration (CR). However, buffaloes fed TR1 and TR2 recorded significantly $(\mathrm{P}<0.05)$ the least amount of DM, TDN, DE and DCP required per $\mathrm{kg} 7 \% \mathrm{FCM}$, while buffaloes fed traditional summer ration $(\mathrm{CR})$ had the highest amounts with significant differences $(\mathrm{P}<0.05)$.

Table (8): Feed conversion and economic efficiency of buffaloes fed the experimental rations.

\begin{tabular}{|c|c|c|c|c|}
\hline \multirow{2}{*}{ Item } & \multirow{2}{*}{$\begin{array}{l}\text { Control ration } \\
\text { (CR) }\end{array}$} & \multicolumn{2}{|c|}{ Tested rations } & \multirow{2}{*}{$\pm \mathrm{SE}$} \\
\hline & & TR1 & TR2 & \\
\hline \multicolumn{5}{|l|}{ Feed conversion: } \\
\hline DM kg/kg 7\%FCM & $1.82^{\mathrm{a}}$ & $1.59^{b}$ & $1.43^{b}$ & 0.061 \\
\hline TDN kg/kg 7\%FCM & $1.04^{\mathrm{a}}$ & $0.93^{b}$ & $0.88^{b}$ & 0.037 \\
\hline DE Mcal/kg 7\%FCM & $4.56^{\mathrm{a}}$ & $4.10^{\mathrm{b}}$ & $3.87^{\mathrm{D}}$ & 0.165 \\
\hline DCP g/kg 7\%FCM & $0.16^{\mathrm{a}}$ & $0.13^{b}$ & $0.11^{\mathrm{b}}$ & 0.005 \\
\hline \multicolumn{5}{|l|}{ Economic efficiency: } \\
\hline Milk price (LE/day) & $32.83^{b}$ & $37.77^{a}$ & $41.41^{\mathrm{a}}$ & 1.609 \\
\hline Feed cost (LE/day) & $18.70^{\mathrm{a}}$ & $16.00^{\mathrm{C}}$ & $17.40^{\mathrm{b}}$ & 1.61 \\
\hline Feed cost $\mathrm{kg} 7 \% \mathrm{FCM}$ & $1.99^{\mathrm{a}}$ & $1.48^{\mathrm{b}}$ & $1.47^{b}$ & 0.065 \\
\hline Revenue (LE/head/day) ${ }^{\star}$ & $14.13^{b}$ & $21.77^{\mathrm{a}}$ & $24.01^{\mathrm{a}}$ & 1.61 \\
\hline $\begin{array}{l}\text { Gross margin over feed } \\
\text { cost (LE/day) }\end{array}$ & $0.76^{\mathrm{b}}$ & $1.36^{\mathrm{a}}$ & $1.38^{\mathrm{a}}$ & 0.096 \\
\hline Economic efficiency ${ }^{\star \star \star}$ & $1.76^{\mathrm{b}}$ & $2.36^{\mathrm{a}}$ & $2.38^{a}$ & 0.096 \\
\hline Improvement & 100.0 & 134.10 & 135.23 & \\
\hline
\end{tabular}

$a$ and $b$ : values in the same row with different superscripts differ significantly $(P<0.05)$

${ }^{*}$ Revenue $=$ money output - money input

${ }^{* *}$ Gross margin over feed = Revenue / feed cost

*** Economical efficiency $=$ money output $/$ money input 
Moreover, buffaloes fed tested rations (TR1 and TR2) attained the best efficiency of protein and energy utilization with nearly similar values, while those fed control ration (CR) recorded the lowest efficiency with significant differences $(P<0.05)$. This could be attributed to the higher daily fed intake by buffaloes fed control ration (CR) above their requirements than those fed other tested rations (TR1 and TR2). These results are in accordance with those obtained by Bendary et al. (2006) who found that incorporation of rice straw silage revealed the best production efficiency in comparison with buffaloes fed traditional summer ration containing $\mathrm{CFM}, \mathrm{BH}$ and RS. Also, Ahmed et al. (2003) indicated that inclusion of corn stalks silage up to $51.3 \%$ in lactating cows rations (on DM basis) did not cause any adverse effects on production efficiency compared with feeding traditional summer rations.

Economic evaluation of milk production as the result of feeding tested silages is presented in Table (8). Daily feed cost decreased with including rice straw silage or corn stalks silage in TR1 and TR2 by 14.44 and $6.95 \%$, as the result of decreasing CFM level in the two tested rations by $20.0 \%$ as shown in Table (6). However, these results are mainly due to the high cost of CFM in control ration in comparison with other tested rations (Table 8).

Moreover, the average daily net out put (revenue) for buffaloes fed tested rations (TR1 and TR2) increased by 7.64 and $10.84 \mathrm{LE} /$ day/head, as well as gross margin over fed cost improved by 78.9 and $100.0 \%$, respectively compared with those fed control ration (CR). However, the gross margin for the total period of feeding animals on green corn stalks and rice straw silages (i.e. 6 months from June to November) was LE 1373.4 and 1951.2 per head, respectively.

These results may be due to the increase of average daily $7 \% \mathrm{FCM}$ by 15.03 and $26.12 \%$ for buffaloes fed TR 1 and TR2, respectively compared with feeding control ration, along with the decrease of feed cost as the result of the reduction of CFM consumption which decreased by $20 \%$ during feeding both tested rations compared with feeding CR as shown in Tables (6 and 7). So, milk producers can raise their income level, if they apply this nutritional package into the regimen of their dairy animals.

Furthermore, economic efficiency as the ratio between price of $7 \%$ FCM produced/costs of feed intake, showed significant increase $(P<0.05)$ with inclusion rice straw and corn stalks silages in the TR1 and TR2 tested rations. The corresponding values of economic efficiency of lactating buffaloes fed CR, TR1 and TR2 were 1.76, 2.36 and 2.38, respectively. Also, the economic efficiency was improved by 34.10 and $35.23 \%$ for animals fed TR1 and TR2 rations, respectively compared with feeding the control ration (CR). These results were attributed to the lower price of rice straw silage and corn stalks silage used in these rations.

\section{CONCLUSIONS}

It could be concluded that inclusion of rice straw silage or corn stalks silage as a basal ration for lactating buffaloes in traditional summer rations led to reduce the amounts of CFM by about $20 \%$, decrease daily feed cost by 
14.44 and $6.95 \%$, increased daily $7 \%$ FCM by 15.03 and $26.12 \%$ and improve economic efficiency, along with limiting the environmental pollution as a result of accumulation of rice straw or corn stalks in the fields or burning them.

\section{REFERENCES}

Abou-Slim, A. A. and M. M. Bendary (2005). Feedstuffs resources in Egypt. Sources and maximization of its utilization. Proc. $2^{\text {nd }}$ Conf. Anim. Prod. Res. Int. Sakha 27-29 Sept. 57-67.

Agricultural Economics, Egypt (1999). Summer and Nili crops. Economic affairs sector, Agricultural Economics Central Administration. Volume 2. Ministry of Agricultural and Land Reclamation, Arab Republic of Egypt.

Agricultural Economics, Egypt (2003). Summer and Nili crops. Economic affairs sector, Agricultural Economics Central Administration. Volume 2, Ministry of Agricultural and Land Reclamation, Arab Republic of Egypt.

Ahmed B. M.; H. T. Taie; M. M. Bendary and K. F. Abdel-Lateif (2003). Influence of dietary corn digestibility, performance and economical efficiency of dairy cattle, Egyptian Journal of Nutrition and Feeds, 6 (Special Issue). 587.

Analytical Chemistry of Foods (1995). Published by Blockie Academic and Professional, an imprint of Chapman \& Hal, Western Cleddens Road, Bishoporiggs, Glasgow G 64 2NZ. UK.

Animal Production Research Institute (APRI, 1997). Animal Nutrition Scientifically and Practically. 1st Ed. Animal Production Research Institute. Agriculture Research Center, Ministry of Agricultural. Dokki. Giza. Egypt (In Arabic).

AOAC (1990). Association of Official Analytical Chemists. Official Methods of Analysis, 15th Ed., Washington, DC.

Bergen, W. G.; E. H. Cash and H. E. Henderson (1974). Changes in nitrogenous compounds of the whole corn plant during ensiling and subsequent effects on dry matter intake by sheep. J. Anim. SCl., 39:629.

Bendary, M. M. and M. A. Younis, (1997). Evaluation of maize stalks for feeding dairy cows, J. Appl. Sci.; 112(8): 11-25.

Bendary, M. M.; GH. A. Ghanem; E. A. Amer and F. A. El-Zeer (2001). Nutritional evaluation ensiling fresh maize stover. The 8th Scientific Conference on Animal Nutrition (Special issue) October, Egypt: 105116.

Bendary, M. M.; GH. A. Ghanem and H. M. A. Gaafar (2006). Utilization of rice straw for feeding ruminants. 2- Productive performance of lactating buffaloes fed rice straw silage. J. Agric. Sci. Mansora Univ., 31(8): 5025-5038. 
Darwish, A., M. M. E. Hassouna; A. M. Rammah and M. M. S. Abd El-Gawad (1989). Fodder beet roots in restricted rations for lactating cows. Third Egyptian-British conference on Animal, Fish and Poultry Production. Alex. 7.10 October 221-229.

Davis, C. L. and R. E. Brown (1970). Metabolic disorders of the ruminant, low fat milk syndrome. In physiology of digestion and metabolism in the ruminant, 545, Ed. by A. T. Phillipson, Oriel Press limited. England.

Duncan, D. B. (1955). Multiple range and multiple F-test. Biometrics, 11:1-42.

El-Ashmawy, M. M. I. (2003). Introducing maize silage in winter feeding under dairy animal farm systems in Africa. Ph.D. degree in African studiesNatural resources (Animal nutrition). The institute of Africa research and studies, Cairo University.

El-Ready, K. F. (2000). Effect of dietary silage on dairy cattle performance. M. Sc. Thesis. Faculty of Agric., Shebin El-Kom, Menoufiya University.

El-Serafi, A. M. (1968). Some nutritional studies on the suitable combination of molasses with certain feeding stuffs. M. SC. Thesis, fac. Agric., Cairo University.

El-Talty, Y. I; M.H .Abd-Gawad and A.E.M. Deif (2009). Silage as unconventional forage in feeding lactating buffaloes. Egyptian $\mathrm{J}$. Nutrition and feeds, 12 (3) special issue: 45- 57.

Ensminger M E., J. Eldfield and W. W. Heinemann (1990). Feeds and feeding $2^{\text {nd }}$ Ed. Text Book. 343. Clovis, California U.S.A.

Ghanem, G. H. A.; E. A. Amer and F. A. El-Zeer (2000). Evaluation of using maize stover silage by sheep. J. Agric. Tanta University. 591:603.

Ghanem, G. H. A.; M. M. Bendary; H. M. A. Gaafar; Draz and M. Z. AbouYoussef (2005). Utilization of rice straw for feeding ruminants. 1Productive performance of lactating cows fed Berseem and different forms of rice straw. Prod. 2nd Conf. Anim. Prod. Res. Int., Sakha 2729 Sept. 155-168.

NRC (1988). Nutrient requirements of dairy cattle $6^{\text {th }}$ Rev. Ed. National Research Council. Acd. Sci. Washington, D. C.

Raafat, M. A. and M. E. Saleh (1962). Efficiency of feed utilization with buffaloes and dairy cattle. Proceedings of the Sec. Anim. Prod. Conf. (March. 3-10) Cairo.

SAS (1996). SAS User's Guide, SAS (Statistical Analysis System) Institute, Cary, NC.

Thomas, C. and P. C. Tomas (1985). Factors affecting the nutritive value of grass silage. (Eds. Cole, D. J and Haresign) Recent advance in Animal Nutr, Butter Worth's London 223.

Van Keulen, J. B. A. Young (1977). Evaluation of acid insoluble ash as a digestibility studies. J. Anim. Sci., 44:282.

Warner, A. C. I. (1964). Production of volatile fatty acids in the rumen. Methods of measurements. Nutr. Abst, and Rev., 34:339. 
El-Giziry, A. A. et al.

الاستفادة من قش الارز فى تغذية المجترات:

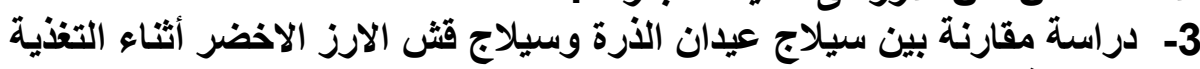

الصيفية.

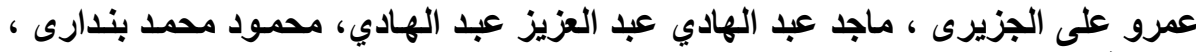

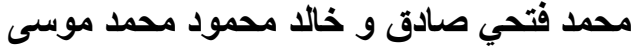

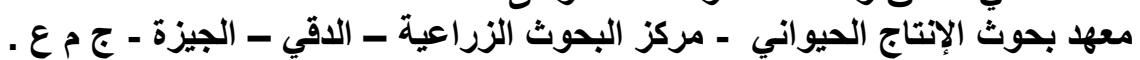

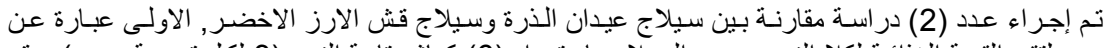

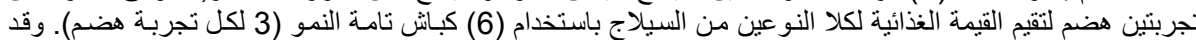

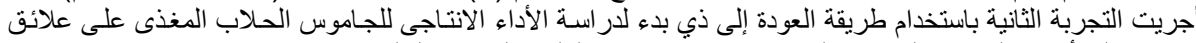

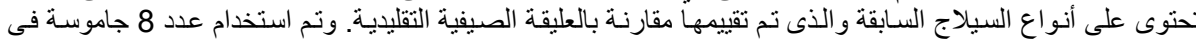

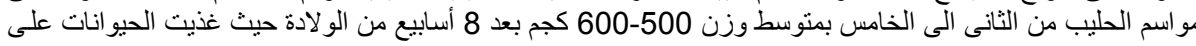

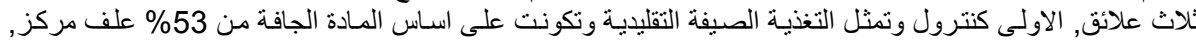

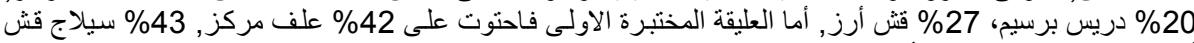

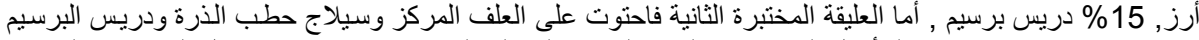

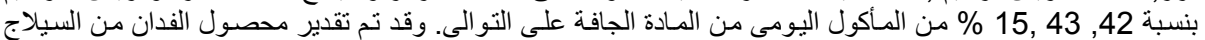

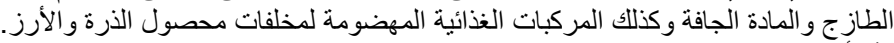
وقد أوضحت النتائج ما يلى إنى:

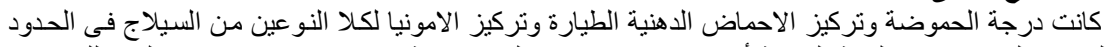

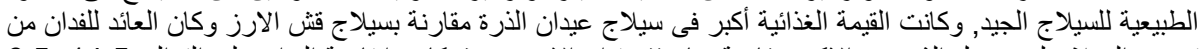

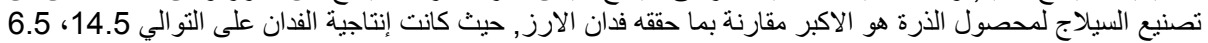

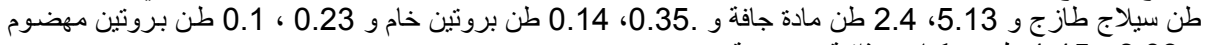

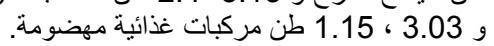

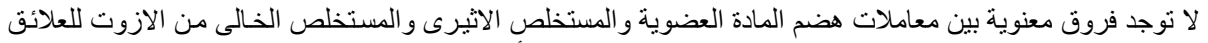

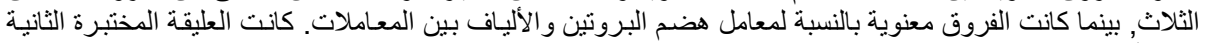

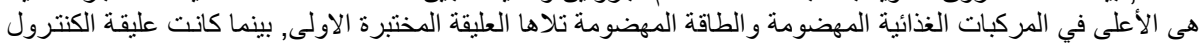

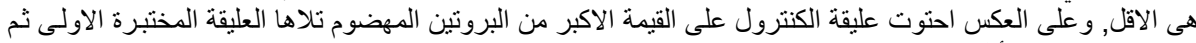

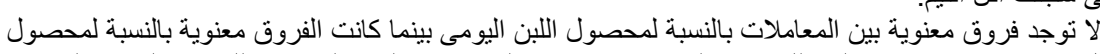
الثانية و التى سجلت أقل القيم.

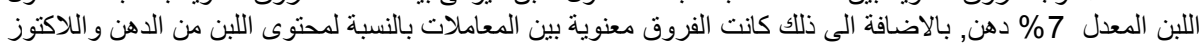

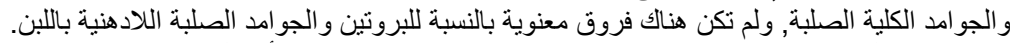

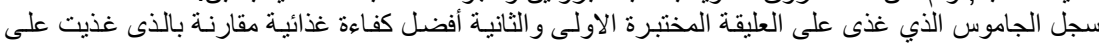

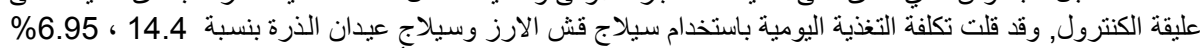

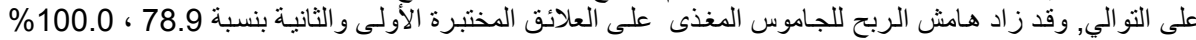

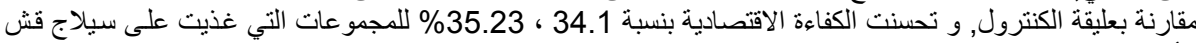

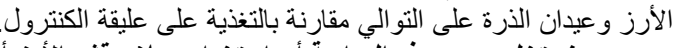

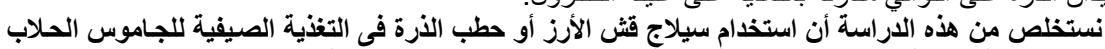

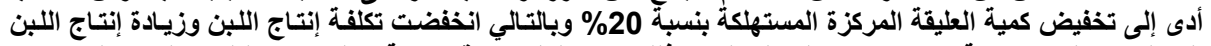

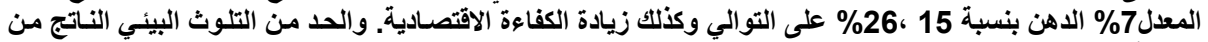
تراكم أو حرق هذه المخلفات.

\author{
كلية الزراعة - جامعة المنصورة \\ مركز البحوث الزراعية
}

$$
\text { قام بتحكيم البحث }
$$

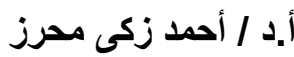
أ.د / أدامل عتمان ابر اهيم 